Article

\title{
Antioxidant Activity of Butyl- and Phenylstannoxanes Derived from 2-, 3- and 4-Pyridinecarboxylic Acids
}

Alicia Corona-Bustamante ${ }^{\mathbf{1}}$, Juan Manuel Viveros-Paredes ${ }^{2}$, Angelina Flores-Parra ${ }^{3}$, Ana Lilia Peraza-Campos ${ }^{1}$, Francisco J. Martínez-Martínez ${ }^{1}$, María Teresa Sumaya-Martínez ${ }^{4}$ and Ángel Ramos-Organillo ${ }^{1, *}$

1 Facultad de Ciencias Químicas, Universidad de Colima, kilómetro 9 carretera Colima, Coquimatlán, Col. Mexico. C.P. 28400, Mexico

2 Centro Universitario de Ciencias Exactas e Ingenierías, Universidad de Guadalajara, Laboratorio de Inmunofarmacología, Blvd. Marcelino García Barragán No. 1421, esq. Calzada Olímpica, C.P. 4430, Guadalajara, Jal., Mexico

3 Departamento de Química, Centro de Investigación y de Estudios Avanzados-IPN. Apartado, Postal 14-740. Mexico 07000, D. F., Mexico

4 Unidad Académica de Agricultura, Universidad Autónoma de Nayarit, Cd. de la Cultura "Amado Nervo", Boulevard Tepic-Xalisco s/n. C.P. 63190. Tepic, Nayarit, Mexico

* Author to whom correspondence should be addressed; E-Mail: aaramos@ucol.mx; Tel.: +523123161163.

Received: 7 May 2010; in revised form: 31 May 2010 / Accepted: 15 July 2010 /

Published: 9 August 2010

Abstract: In vitro antioxidant activity for 12 stannoxanes derived from $\mathrm{Ph}_{3} \mathrm{SnCl}$ (compounds 1-3), $\mathrm{Ph}_{2} \mathrm{SnCl}_{2}$ (compounds 4-6), $\mathrm{Bu}_{3} \mathrm{SnCl}$ (compounds 7-9), and $\mathrm{Bu}_{2} \mathrm{SnCl}_{2}$ (compounds 10-12), was assayed qualitatively by the chromatographic profile with 1,1diphenyl-2-picrylhydrazil (DPPH) method and by two quantitative methods: the DPPH radical scavenging activity and Ferric-Reducing Antioxidant Power (FRAP) assays. The results were compared with those obtained with the starting materials 2-pyridinecarboxylic acid (I), 3-pyridinecarboxylic acid (II) and 4-pyridinecarboxylic acid (III), as well as with standard compounds, such as vitamin $\mathrm{C}$ and vitamin $\mathrm{E}$, respectively. The in vitro antiradical activity with DPPH of diphenyltin derivative 5 showed a very similar behavior to vitamin $\mathrm{C}$ at a $20 \mu \mathrm{g} / \mathrm{mL}$ concentration, whereas according to the FRAP method, compound 8 was better. This difference is due to the mechanism of the antioxidant process. The Structure-Activity Relationships (SAR) for both methods is also reported. 
Keywords: antioxidant activity; pyridinecarboxylate; organotin; DPPH; ferric-reducing

\section{Introduction}

Bioorganometallic chemistry is dedicated to the study of metallic complexes as well as their biological applications, with a view to designing new drugs offering better performance than those already known. Molecules have been designed for the treatment of cancer [1-3], Alzheimer's [4], neurodegenerative diseases [5], as therapeutic and diagnosis agents [6], microbiocides [7,8], chelators[9], among others, where the principal characteristic is the presence of a metallic moiety which increases the biological activity compared to the free organic ligand.

Involved in organometallic chemistry, we are interested in the structural and pharmacological activity of metallic complexes of group 14 . These elements have shown great chemical versatility, as a result of their diverse electronegativities and their ability to increase their coordination spheres [10]. Germanium complexes are used in the fabrication of electronic components, chemotherapeutics, and as radioprotective agents [11], while complexes derived from heavier metals like tin and lead are relevant for their industrial applications as well as for their pharmacological and toxicological activities [11].

Applications of organotin(IV) compounds, especially those derived from carboxylate ligands, as bactericides [12-16], antitumoral [17-19], anti-inflammatory [20,21] and antifungal agents $[13,15,16,22]$, as wood preservatives and as catalysts [23-25] and pesticides have been exhaustively studied to find the best performance depending on the ligand attached to the organometallic fragment, as well as the origin of the organotin moiety.

This research is focused on the antioxidant activity of Sn(IV) compounds, to find out if there is an increased activity with the presence of the metallic center. Some authors have indicated that the antioxidant capacity of some flavonoids, like quercetin, is increased when it is complexed with a metallic moiety, for example $\mathrm{Cu}$ (II) [26], $\mathrm{Cr}$ (III) [27] or $\mathrm{Co}(\mathrm{II})$ [28]. There is little information however on a similar trend of Sn(IV) compounds; although there is information where authors refer that an equimolar mixture of the kaempeferol or quercetin (natural antioxidants) with diphenyltin dichloride $\left(\mathrm{Ph}_{2} \mathrm{SnCl}_{2}\right)$ or triphenyltin chloride $\left(\mathrm{Ph}_{3} \mathrm{SnCl}\right)$ resulted in a higher antioxidant activity than that of kaempeferol or quercetin alone [29,30].

\section{Results and Discussion}

Pyridinecarboxylic acid isomers I-III (Figure 1) are ligands with known biological activity [31-35], but no antioxidant activity is reported for any of them as we could corroborate running the DPPH and FRAP methods used in this work. The stannoxanes were synthesized as reported in the literature, all spectroscopic data are according to those reported for compounds 1-3 [36,37], 7-9 [38] and for 4-6 [36,39]. Here we have included the microanalyses as further evidence. 
Figure 1. Ligands used to synthesize stannoxanes 1-12.<smiles>O=C(O)c1ccccn1</smiles>

$\bigcirc=$ lone pair<smiles>O=C(O)c1cccnc1</smiles><smiles>O=C(O)c1ccncc1</smiles>

Compounds 10-12 were synthesized using a modified method reported by Gielen [40], the details and spectroscopic data for those compounds are summarized in the Experimental section and the structures are shown in Figure 2.

Figure 2. Structures for stannoxanes derived from 2-, 3- and 4-pyridinecarboxylic acids; pentacoordinated triphenylstannoxanes 1-3 [36,37]; hexacoordinated diphenylstannoxanes 4-6 [36,39]; tetracoordinated tributylstannoxanes 7-9 [38]; pentacoordinated dibutylstannoxanes 10-12.

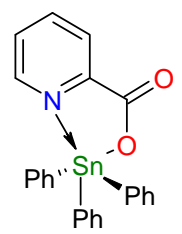

1<smiles></smiles>

4<smiles>O=C(O[Sn](Br)(Br)CBr)c1ccccn1</smiles>

7<smiles>CO[Si](Br)(Br)(Br)OC(=O)c1ccccn1</smiles>

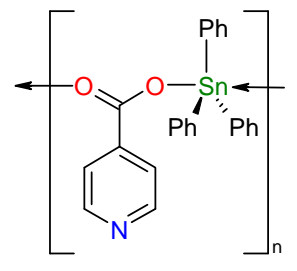

3

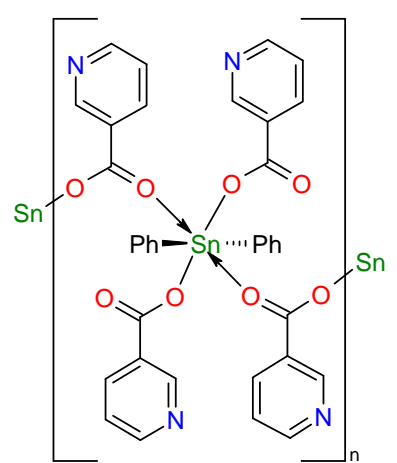

5<smiles>O=C(O[Sn](Br)(Br)Br)c1cccnc1</smiles>

8<smiles>C[Sn](Br)(Br)OC(=O)c1ccncc1</smiles>

9<smiles></smiles><smiles></smiles> 
Tin atom coordination number is important because the SAR analysis depends on it; this information allows us to compare the antioxidant activity of stannoxanes 1-12 (Figure 2) with other reported activities, such as antitumoral and bactericidal activities. In Figure 2 different stannoxane structures may be observed: the presence of $\mathrm{N}$ atom and the versatility of carboxylic group showed a variety of geometries such as tetrahedral (7-9), bipyramidal trigonal (1-3 y 10-12) and octahedral (4-6) in addition to the higher solubility in non-polar solvents provided by butyl rather than phenyl entities.

\subsection{Thin Layer Chromatographic (TLC) profile modified with DPPH method}

A very useful method to measure the antiradical activity of a compound is the one based on the use of the stable free radical DPPH, the electronic delocalization of this radical is responsible for its characteristic deep violet color. Compounds capable of donating a hydrogen atom will convert the DPPH radical into its reduced form, a neutral stable molecule, resulting in a color switch from deep violet to pale yellow [41,42], this method was selected because of its simplicity and worldwide acceptance, and the fact it enables us to compare results [43] with the ones already reported.

This assay was performed before the quantitative method to determine if stannoxanes were capable of stabilizing a radical molecule or not. No data concerning this kind of assays with stannoxanes could be found in the literature, so no comparison with other stannoxanes was possible. Nevertheless, there are reports concerning quantitative assays with metallic complexes of metals other than Sn(IV), which will also be discussed.

Compounds 2, 3, 5, 6, 8, 9, 10 and 11 presented discoloration on the application zone in the Thin Layer Chromatography (TLC) assay (Figure 3) which indicated that these compounds could have interesting results in the quantitative in vitro evaluation using the same radical.

Figure 3. TLC fingerprints of stannoxanes vs vitamin $\mathrm{C}$ at $200 \mu \mathrm{g} / \mathrm{mL}$ in $0.2 \%$ methanolic DPPH solution, after 5-8 min.

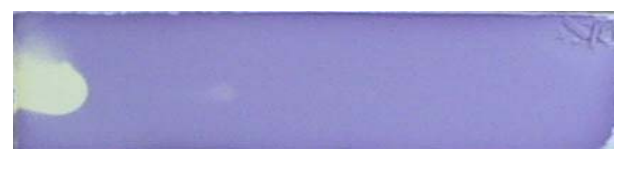

Vit C I II $\quad$ III

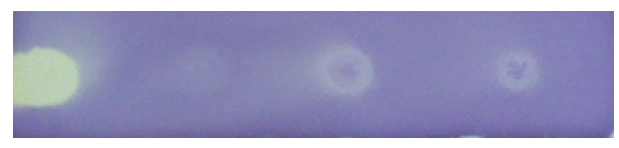

Vit C 1

2

3

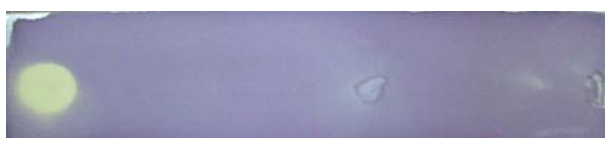

$\begin{array}{llll}\text { Vit C } & 4 & 5 & 6\end{array}$

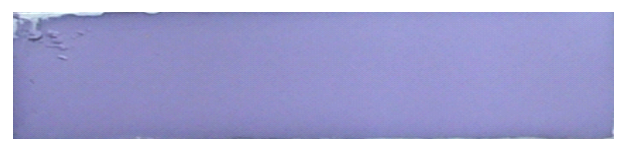

$\mathrm{CHCl}_{3}$

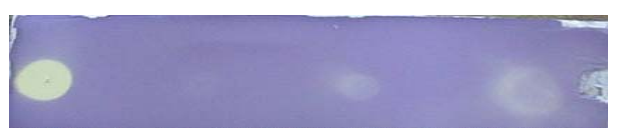

$\begin{array}{llll}\text { Vit C } & 7 & 8 & 9\end{array}$

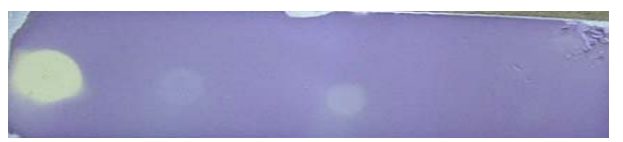

$\begin{array}{lll}\text { Vit C } & 10 & 11\end{array}$
12 


\subsection{DPPH radical scavenging activity}

There are literature reports of metallic complexes where the ligand has antioxidant activity and it is expected that the metal moiety will increase its activity [26,29,44-46]. In this case, the three heterocarboxylic acid isomers show a moderated antioxidant activity even though, their use in diverse applications has been reported, for example, ligand II is an antihyperlipidemic drug and its widely used in patients with atherosclerosis [47]; also for ligand III, some authors refer its wide biological applications but these do not include antioxidant activity [48]. Ligands I-III (Figure 1), were tested for their antiradical activity at a concentration of $20 \mu \mathrm{g} / \mathrm{mL}$. Figure 4 shows the antiradical activity of free ligands I-III at 60 min compared with vitamin $\mathrm{C}$; the three isomers reach scarcely the $50 \%$ of antiradical activity. This information is consistent with that reported in a study on the inhibition of oxidation of Low Density Lipoproteins (LDL) where authors found that 2,6-pyridinedicarboxylic acid inhibited the oxidation of LDL, and no such activity on LDL was found for 2-pyridinecarboxylic acid (ligand I) [49].

Figure 4. DPPH scavenging activity of ligands I-III vs vitamin C. Ligands I-III and vitamin $\mathrm{C}$ standard were analyzed at $20 \mu \mathrm{g} / \mathrm{mL}$ DMSO solutions at $\mathrm{T}=60 \mathrm{~min}$.

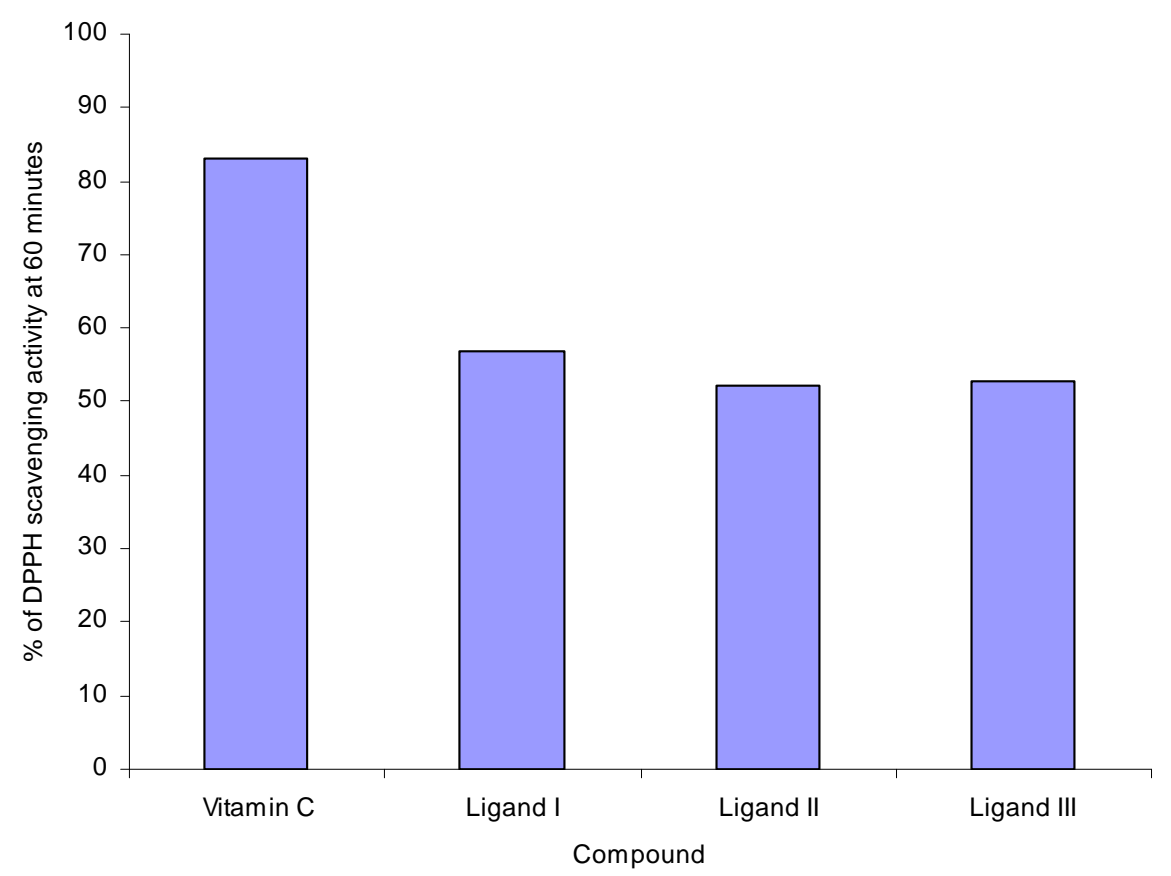

Next the antiradical activity of the stannoxane complexes was tested at $60 \mathrm{~min}$ at a $20 \mu \mathrm{g} / \mathrm{mL}$ concentration in order to identify the molecule with best activity for each compound and be able to evaluate the structure-activity relationship [42,50].

The evaluation of stannoxanes proceeded under the same conditions as for ligands I-III, and the DPPH scavenging activity results for stannoxanes 1-12, showed that stannoxanes 5, 6 and 11 (Figure 5) presented the best percentage of antiradical activity. 
Figure 5. DPPH scavenging activity at $\mathrm{T}=60 \mathrm{~min}$. Stannoxanes and standard vitamin $\mathrm{C}$ were analyzed as $20 \mu \mathrm{g} / \mathrm{mL}$ DMSO solutions.

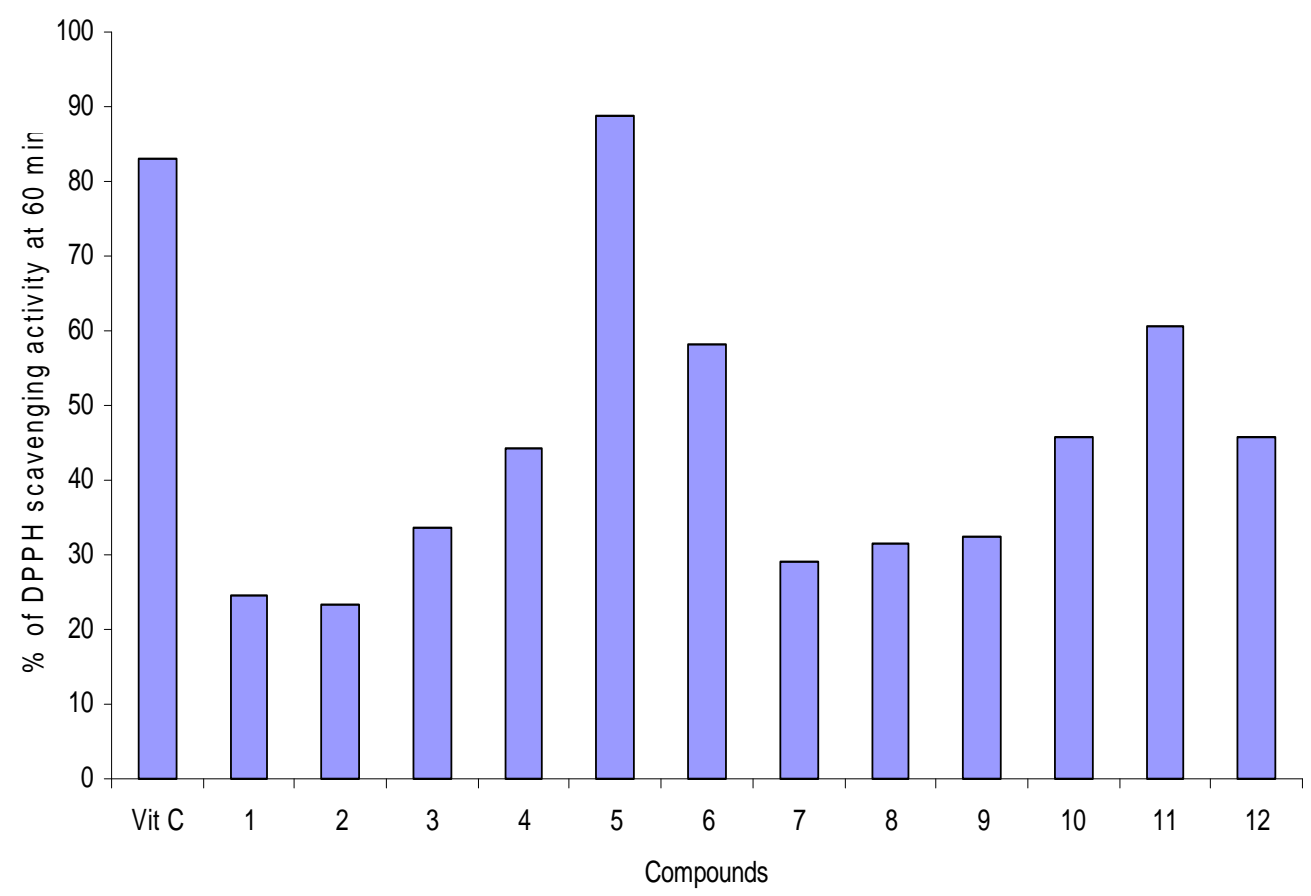

The presence of the metallic moiety increased the antioxidant activity of the ligand because their proton donor capacity was enhanced. It is important to notice that stannoxane $\mathbf{5}$ had a very similar behavior to vitamin $\mathrm{C}$.

This is a promising result in the wide spectrum biological activity of organotin(IV) compounds; because this kind of compounds could also show a relevant antioxidant activity despite the fact of their implicit toxicity [51]. It seems that a diphenyltin moiety could participate in the antioxidative activity. Gabrielska et al. [29] found that the addition of $\mathrm{Ph}_{2} \mathrm{SnCl}_{2}$ to quercetin increased its antioxidant activity. In our research, ligand II did show a moderate antioxidant activity towards the DPPH stable free radical, but the complex derived from this ligand and $\mathrm{Ph}_{2} \mathrm{SnCl}_{2}$ (Figure 2, compound 5) did show a high percentage of scavenging activity (Figure 5). This information confirms that the observed antioxidant activity is increased by the presence of a $\mathrm{Sn}(\mathrm{IV})$ metal center, as previously reported for other metals $[26,44,45]$.

The effect of stannoxanes 5, 6 and 11 on DPPH radical scavenging could be due to their hydrogen donating ability. A possible exchanging mechanism is that in which a proton from the ligand is donated and the charge is stabilized through the entire complex, changing its charge delocalization capacity as shown in Scheme 1. The structure-activity relationship of the 12 stannoxanes (Figure 5) presents a behavior in which hexa- and pentacoordinated compounds (4-6 and 10-12) are the most capable for antiradical activity with DPPH. In the hexa- and pentacoordinated compounds the pyridine nuclei is uncovered in the structure because of the intramolecular coordination of the carboxylic group, except for compounds 4 and 10, where the nitrogen of the pyridine nuclei is coordinating to the $\mathrm{Sn}(\mathrm{IV})$ center; for compounds 10-12 the presence of a $\mathrm{O}-\mathrm{CH}_{3}$ group favors the proton donating ability. Compound 5 showed the best antiradical activity of the 12 stannoxanes. 
Scheme 1. Proposed mechanism for DPPH scavenging activity for compound 5.

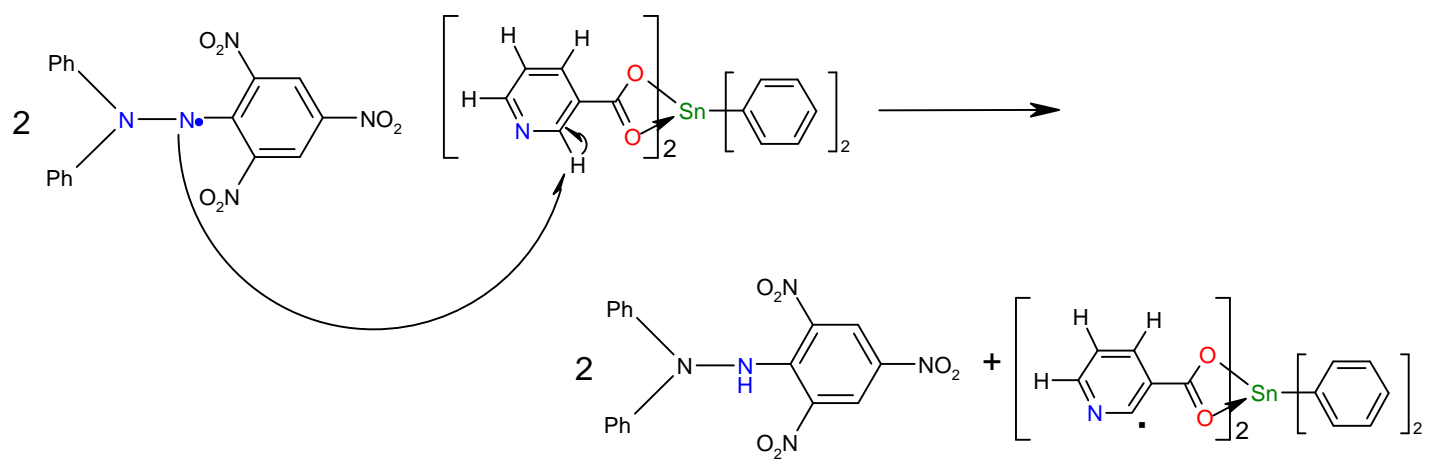

\subsection{Ferric-reducing antioxidant power assay (FRAP)}

We have screened antioxidant activity of the stannoxanes to evaluate their electron-donating activity [52] by the FRAP method, which is one of the most commonly used for this purpose. FRAP capacity was assayed for ligands I-III (Figure 1) and stannoxanes 1-12 (Figure 2) at a concentration of $2 \mu \mathrm{g} / \mathrm{mL}$. Results are reported as absorbance at $700 \mathrm{~nm}$ (Figure 6). The 12 stannoxanes and ligands IIII did show significant Fe(III) reducing capacity $(\mathrm{p}<0.05)$. Compound 8 showed the best reducing capacity among those derived from tributyltin. The final ranking was: $\mathbf{8}>\mathbf{7}=\mathbf{3}>\mathbf{I I I}>\mathbf{I I}=\mathbf{4}=\mathbf{1 0}$.

Figure 6. Iron(III) to Iron(II) reducing capacity for organic free ligands and stannoxanes at a $2 \mu \mathrm{g} / \mathrm{mL}$ concentration reported as absorbance formed at $700 \mathrm{~nm}$.

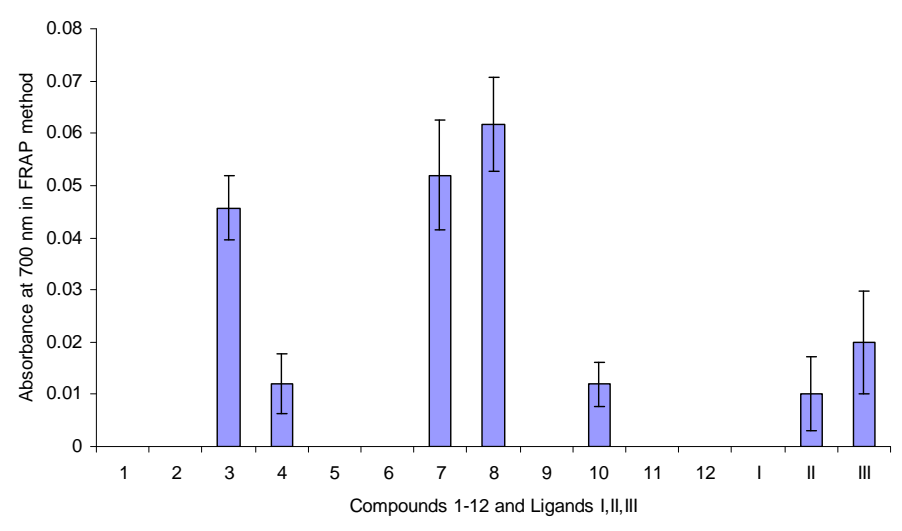

Analyzing their structures, their electron donating capacity can be explained by the presence of the free carboxylate group, as in the case of compounds $\mathbf{4}$ and $\mathbf{3}$ derived from diphenyltin and triphenyltin, respectively. We can argue that the electron-donating character of butyl group in $\mathbf{8}$ and $\mathbf{7}$, and the electron-withdrawal of phenyl group in $\mathbf{4}$ and $\mathbf{3}$ are not determining their ferric-reducing power, in contrast to the coordination form of tin entity, because $\mathbf{8}$ and $\mathbf{7}$ are tetracoordinated and $\mathbf{4}$ and $\mathbf{3}$ are hexacoordinated molecules.

There are no data to compare these results with other metallic complexes; especially with organometallic compounds derived from $\mathrm{Sn}(\mathrm{IV})$. In this research, it is proposed a mechanism where an electron is donated in all analyzed complexes, the carboxylate group is exposed and the radical cation is delocalized through a four-member heterometallic cycle (Scheme 2). We continue working on this field to confirm this statement. 
Scheme 2. Proposed mechanism for FRAP method for tributyltin derivatives.

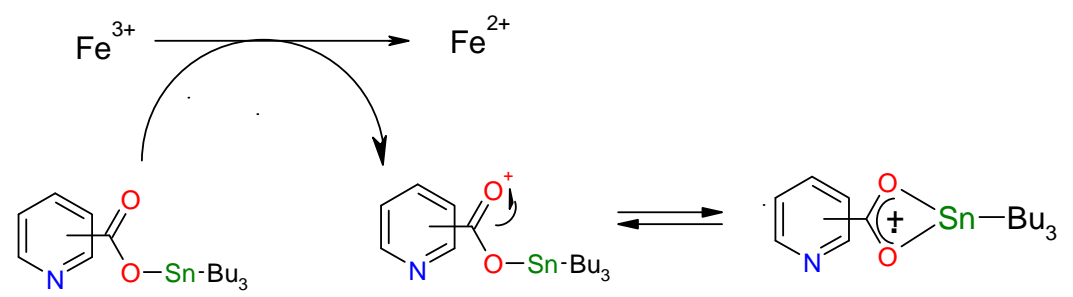

\section{Experimental}

\subsection{General}

For the synthesis of compounds 1-12, all chemicals were reagent grade and were used without further purification. For the characterization of the compounds to compare results with those reported in the literature, melting points were measured by the capillary method in a Mel-Temp apparatus, and data are uncorrected. IR spectra were recorded on a Perkin Elmer FT-IR 1600 spectrophotometer using an ATR unit for solids in the 4,000-400 $\mathrm{cm}^{-1}$ range. The NMR spectra were obtained in $\mathrm{CDCl}_{3}$ and DMSO- $\mathrm{d}_{6}$ on Bruker $300 \mathrm{MHz}$ or Jeol Eclipse $400 \mathrm{MHz}$ spectrometers operations at $300.13185 \mathrm{MHz}$ or $399.78219 \mathrm{MHz}$ for ${ }^{1} \mathrm{H}$ and75.47564 MHz or $100.52530 \mathrm{MHz}$ for ${ }^{13} \mathrm{C}$, respectively, using TMS as internal reference, and $\mathrm{Me}_{4} \mathrm{Sn}$ for ${ }^{119} \mathrm{Sn}(111.92607 \mathrm{MHz}$ or 149.08124), respectively. Chemical shifts ( $\delta)$ are reported in ppm [53]. For compounds $\mathbf{1 0}$ and $\mathbf{1 2}$ the ${ }^{119} \mathrm{Sn}$ data was not recorded because of the insolubility of the mixture in DMSO- $\mathrm{d}_{6}$, and the partial solubility just let us obtain the ${ }^{1} \mathrm{H}$ and ${ }^{13} \mathrm{C}$ data. Antiradical activity with DPPH absorbance was measured with a Bio-Rad Benchmark microplate reader at $570 \mathrm{~nm}$. Ferric-reducing antioxidant power assay absorbance was measured on a Perkin Elmer Lambda 2S UV/VIS spectrometer at $700 \mathrm{~nm}$, the incubation of the samples was carried out at Pierce Reacti-Therm Heating Module and centrifugation of the samples was done at a Heraeus $3_{\mathrm{S}-\mathrm{R}}$ multifuge.

\subsection{Synthesis}

Organotin compounds were synthesized following the method reported by Gielen et al. [40] with some modifications. The reactions were carried out in benzene solution for complexes 1-3 and 7-9 and in a mixture of toluene/methanol for complexes 4-6 and 10-12 to assure the synthesis and purity of compounds the ${ }^{1} \mathrm{H}$, IR spectra and melting point (m.p.) data were compared with those reported in literature; for compounds 1-3 [36,37], for 4-6 [36,39], and for 7-9 [38], these all were in agreement.

Triphenyltin(IV) 2-pyridinecarboxylate (1). White powder, yield 95\%, IR (solid, v): 1329 (C=O sym), $1675\left(\mathrm{C}=\mathrm{O}\right.$ asym), $1598\left(\mathrm{C}=\mathrm{C}\right.$ py), $1432\left(\mathrm{C}=\mathrm{N}\right.$ py), $532(\mathrm{Sn}-\mathrm{C}), 436(\mathrm{Sn}-\mathrm{O}) ; \mathrm{NMR}\left(\mathrm{CDCl}_{3}\right)$ : ${ }^{119} \mathrm{Sn}:-26.3$; ${ }^{1} \mathrm{H}$ : H3 (8.39), H4 (7.98), H5 (7.53), H6 (8.61), H9 (7.55), H10 (7.21), H11 (7.21); Elem. anal.: $\left[\mathrm{C}_{24} \mathrm{H}_{19} \mathrm{NO}_{2} \mathrm{Sn}\right]$ Calc. C (61.06), H (4.6), N (2.97). Found C (61.01), H (4.12), N (2.84).

Triphenyltin(IV) 3-pyridinecarboxylate (2). White powder, yield 24\%, IR (solid, v): 1426 (C=O sym), $1650\left(\mathrm{C}=\mathrm{O}\right.$ asym), $1592\left(\mathrm{C}=\mathrm{C}\right.$ py), $1479\left(\mathrm{C}=\mathrm{N}\right.$ py), $509(\mathrm{Sn}-\mathrm{C}), 492(\mathrm{Sn}-\mathrm{O}) ; \mathrm{NMR}\left(\mathrm{CDCl}_{3}\right)$ : 
${ }^{119}$ Sn: -107; ${ }^{1} \mathrm{H}$ : H2 (9.2), H4 (7.3), H5 (8.3), H6 (8.6), H9 (7.79), H10 (7.48), H11 (7.46); Elem. anal.: $\left[\mathrm{C}_{24} \mathrm{H}_{19} \mathrm{NO}_{2} \mathrm{Sn}\right]$ Calc. C (61.06), H (4.6), N (2.97). Found. C (60.66), H (4.05), N (2.90).

Triphenyltin(IV) 4-pyridinecarboxylate (3). White powder, yield 86\%, IR (solid, v): 1344 (C=O sym), 1646 ( $\mathrm{C}=\mathrm{O}$ asym), 1543 ( $\mathrm{C}=\mathrm{C}$ py), 1473 ( $\mathrm{C}=\mathrm{N}$ py), $517(\mathrm{Sn}-\mathrm{C}), 491(\mathrm{Sn}-\mathrm{O})$; NMR $\left(\mathrm{CDCl}_{3}\right):{ }^{119} \mathrm{Sn}:$ 112; ${ }^{1} \mathrm{H}$ : H2 (7.88), H3 (8.59), H5 (8.59), H6 (7.88), H9 (7.81), H10 (7.47), H11 (7.47); Elem. anal.: $\left[\mathrm{C}_{24} \mathrm{H}_{19} \mathrm{NO}_{2} \mathrm{Sn}\right]$ Calc. C (61.06), H (4.6), N (2.97). Found C (60.10), H (3.98), N (2.87).

Diphenyltin(IV) 2-pyridinecarboxylate (4). White powder, yield 31\%, IR (solid, v): 1326 (C=O sym), $1673\left(\mathrm{C}=\mathrm{O}\right.$ asym), $1595\left(\mathrm{C}=\mathrm{C}\right.$ py), $1461\left(\mathrm{C}=\mathrm{N}\right.$ py), $526(\mathrm{Sn}-\mathrm{C}), 473(\mathrm{Sn}-\mathrm{O}) ; \mathrm{NMR}\left(\mathrm{CDCl}_{3}\right)$ : ${ }^{119} \mathrm{Sn}:-427$; ${ }^{1} \mathrm{H}$ : H3 (8.35), H4 (7.98), H5 (7.51), H6 (8.67), H9 (7.52), H10 (7.2), H11 (7.19); Elem. anal.: $\left[\mathrm{C}_{24} \mathrm{H}_{18} \mathrm{~N}_{2} \mathrm{O}_{4} \mathrm{Sn} \cdot \mathrm{C}_{6} \mathrm{H}_{6}\right]$ Calc. C (60.54), H (4.06), N (4.71); Found C (59.18), H (4.85), N (3.97).

Diphenyltin(IV) 3-pyridinecarboxylate (5). White powder, yield 23\%, IR (solid, v): 1360 (C=O sym), $1651\left(\mathrm{C}=\mathrm{O}\right.$ asym), $1585\left(\mathrm{C}=\mathrm{C}\right.$ py), $1467\left(\mathrm{C}=\mathrm{N}\right.$ py), $491(\mathrm{Sn}-\mathrm{C}), 490(\mathrm{Sn}-\mathrm{O})$; NMR $\left(\mathrm{DMSO}-\mathrm{d}_{6}\right):{ }^{119} \mathrm{Sn}$ : -233.5; ${ }^{1} \mathrm{H}$ : H2 (9.07), H4 (7.56), H5 (8.37), H6 (8.71), H9 (7.85), H10 (7.26), H11 (7.26); Elem. anal.: $\left[\mathrm{C}_{24} \mathrm{H}_{18} \mathrm{~N}_{2} \mathrm{O}_{4} \mathrm{Sn} \cdot \mathrm{C}_{6} \mathrm{H}_{6}\right]$ Calc. C (60.54), H (4.06), N (4.71); Found C (59.98), H (4.62), N (4.50).

Diphenyltin(IV) 4-pyridinecarboxylate (6). White powder, yield 35\%, IR (solid, v): 1341 (C=O sym), $1641\left(\mathrm{C}=\mathrm{O}\right.$ asym), $1549\left(\mathrm{C}=\mathrm{C}\right.$ py), $1479\left(\mathrm{C}=\mathrm{N}\right.$ py), $534(\mathrm{Sn}-\mathrm{C}), 492(\mathrm{Sn}-\mathrm{O}) ; \mathrm{NMR}\left(\mathrm{CDCl}_{3}\right)$ : ${ }^{119} \mathrm{Sn}:-233.5$; ${ }^{1} \mathrm{H}$ : H2 (7.58), H3 (8.33), H5 (8.33), H6 (7.58), H9 (7.73), H10 (7.14), H11 (7.14); Elem. anal.: $\left[\mathrm{C}_{24} \mathrm{H}_{18} \mathrm{~N}_{2} \mathrm{O}_{4} \mathrm{Sn} \cdot \mathrm{C}_{6} \mathrm{H}_{6}\right]$ Calc. C (60.54), H (4.06), N (4.71); Found C (59.75), H (4.22), N (4.12).

Tributyltin(IV) 2-pyridinecarboxylate (7). Yellow liquid, yield $>90 \%$, IR (liquid, v): 1395 (C=O sym), $1553\left(\mathrm{C}=\mathrm{O}\right.$ asym), 541 (Sn-C), 496 (Sn-O); NMR $\left(\mathrm{CDCl}_{3}\right):{ }^{119} \mathrm{Sn}:+115.0 ;{ }^{1} \mathrm{H}: \mathrm{H} 3$ (8.09), H4 (7.71), H5 (7.31), H6 (8.64), H8 (1.58), H9 (1.28), H10 (1.28), H11 (1.28); Elem. anal.: [ $\left.\mathrm{C}_{18} \mathrm{H}_{31} \mathrm{NO}_{2} \mathrm{Sn}\right]$ Calc. C (52.46), H (7.58), N (3.40). Found C (52.35), H (7.97), N (3.80).

Tributyltin(IV) 3-pyridinecarboxylate (8). Yellow liquid, yield $>90 \%$, IR (liquid, v): 1344 (C=O sym), $1625\left(\mathrm{C}=\mathrm{O}\right.$ asym), $1460\left(\mathrm{C}=\mathrm{N}\right.$ py), $557(\mathrm{Sn}-\mathrm{C}), 506(\mathrm{Sn}-\mathrm{O})$; NMR $\left(\mathrm{CDCl}_{3}\right):{ }^{119} \mathrm{Sn}:+117.5 ;{ }^{1} \mathrm{H}: \mathrm{H} 2$ (9.1), H4 (7.2), H5 (8.2), H6 (8.6), H8 (1.63), H9 (1.34), H10 (1.34), H11 (1.34); Elem. anal.: $\left[\mathrm{C}_{18} \mathrm{H}_{31} \mathrm{NO}_{2} \mathrm{Sn}\right]$ Calc. C (52.46), H (7.58), N (3.40). Found C (52.13), H (8.12), N (3.80).

Tributyltin(IV) 4-pyridinecarboxylate (9). White powder, yield 23\%, IR (solid, v): 1348 (C=O sym), $1646\left(\mathrm{C}=\mathrm{O}\right.$ asym), 1603 ( $\mathrm{C}=\mathrm{C}$ py), $1460\left(\mathrm{C}=\mathrm{N}\right.$ py), $521(\mathrm{Sn}-\mathrm{C}), 492(\mathrm{Sn}-\mathrm{O})$; NMR $\left(\mathrm{CDCl}_{3}\right):{ }^{119} \mathrm{Sn}$ : +116.8; ${ }^{1} \mathrm{H}$ : H2 (8.62), H3 (7.81), H5 (7.81), H6 (8.62), H8 (1.58), H9 (1.29), H10 (1.29), H11 (1.31); Elem. anal.: [ $\left.\mathrm{C}_{18} \mathrm{H}_{31} \mathrm{NO}_{2} \mathrm{Sn}\right]$ Calc. C (52.46), H (7.58), N (3.40). Found C (52.59), H (8.09), N (3.83).

Dibutyltin(IV) methoxy-2-pyridinecarboxylate $\left[\left(\mathrm{C}_{6} \mathrm{H}_{4} \mathrm{NO}_{2}\right)\left(\mathrm{CH}_{3} \mathrm{O}\right) \mathrm{Sn}\left(\mathrm{C}_{4} \mathrm{H}_{9}\right)_{2}\right](\mathbf{1 0})$. General procedure: a solution of $\mathbf{I}(0.5 \mathrm{~g}, 4.06 \mathrm{mmol})$ and $\mathrm{Et}_{3} \mathrm{~N}(0.6 \mathrm{~mL}, 0.436 \mathrm{~g}, 4.30 \mathrm{mmol})$ in toluene $(30 \mathrm{~mL})$ and ethanol $(30 \mathrm{~mL})$ was mixed with continuous stirring with another solution of dibutyltin chloride $(1.39 \mathrm{~g}, 4.57 \mathrm{mmol})$ and $\mathrm{Et}_{3} \mathrm{~N}(0.6 \mathrm{~mL}, 0.436 \mathrm{~g}, 4.30 \mathrm{mmol})$ in toluene $(30 \mathrm{~mL})$ and ethanol $(10 \mathrm{~mL})$. The resulting mixture was heated by $8 \mathrm{~h}$ with continuous stirring. At the end of the reaction, the 
mixture was filtered off and the solvent was evaporated at low pressure, the resulting product was washed with chloroform to give a white powder, yield 90\%, m.p. $146-148{ }^{\circ} \mathrm{C}$, IR (solid, v): 1346 $(\mathrm{C}=\mathrm{O}$ sym), $1664(\mathrm{C}=\mathrm{O}$ asym), $1620(\mathrm{C}=\mathrm{C}$ py), $1457(\mathrm{C}=\mathrm{N}$ py), 541 (Sn-C), 468 (Sn-O); NMR (DMSO-d D $:{ }^{119} \mathrm{Sn}$ : not observed; ${ }^{1} \mathrm{H}$ : H3 (8.38), H4 (8.02), H5 (7.60), H6 (8.98), H8 (1.30), H9 (1.12), H10 (1.12), H11 (1.30), O-Me (3.01); ${ }^{13} \mathrm{C}: \mathrm{C} 2$ (147.5), C3 (127.6), C4 (140.5), C5 (125.6), C6 (146), C7 (166.7), C8 (28.8), C9 (27.6), C10 (26.4), C11 (13.6), O-Me (46.5); Elem. anal.: [ $\left.\mathrm{C}_{15} \mathrm{H}_{25} \mathrm{NO}_{3} \mathrm{Sn}\right]$ Calc. C (46.67), H (6.53), N (3.63). Found C (45.91), H (7.06), N (3.91).

Dibutyltin(IV)-methoxy-3-pyridinecarboxylate $\left[\left(\mathrm{C}_{6} \mathrm{H}_{4} \mathrm{NO}_{2}\right)\left(\mathrm{CH}_{3} \mathrm{O}\right) \mathrm{Sn}\left(\mathrm{C}_{4} \mathrm{H}_{9}\right)_{2}\right]$ (11). Using the same method reported for 10, II $(0.5 \mathrm{~g}, 4.06 \mathrm{mmol})$ and $\mathrm{Et}_{3} \mathrm{~N}(0.6 \mathrm{~mL}, 0.436 \mathrm{~g}, 4.30 \mathrm{mmol})$ in a solution of toluene $(30 \mathrm{~mL})$ and ethanol $(10 \mathrm{~mL})$ was mixed with dibutyltin dichloride $(1.39 \mathrm{~g}, 4.57 \mathrm{mmol})$ and $\mathrm{Et}_{3} \mathrm{~N}(0.6 \mathrm{~mL}, 0.436 \mathrm{~g}, 4.30 \mathrm{mmol})$ in a mixture of toluene $(30 \mathrm{~mL})$ and ethanol $(10 \mathrm{~mL})$. Yield $36 \%$, m.p. $188-190{ }^{\circ} \mathrm{C}$, IR (solid, v): $1395(\mathrm{C}=\mathrm{O}$ sym), $1599(\mathrm{C}=\mathrm{O}$ asym), $1551(\mathrm{C}=\mathrm{C}$ py), $1459(\mathrm{C}=\mathrm{N}$ py), 543 (Sn-C), 438 (Sn-O); NMR ( $\left.\mathrm{CDCl}_{3}\right):{ }^{119} \mathrm{Sn}:-211 ;{ }^{1} \mathrm{H}: \mathrm{H} 2$ (9.09), H4 (7.32), H5 (8.19), H6 (8.63), H8 (1.59), H9 (1.25), H10 (1.25), H11(0.755), O-Me (3.03); ${ }^{13} \mathrm{C}: \mathrm{C} 2$ (151.3), C3 (130), C4 (137.8), C5 (123.6), C6 (153), C7 (171.7), C8 (27.7), C9 (27.0), C10 (27.0), C11 (13.9), O-Me (45.8); Elem. anal. $\left[\mathrm{C}_{15} \mathrm{H}_{25} \mathrm{NO}_{3} \mathrm{Sn}\right]$ Calc. C (46.67), H (6.53), N (3.63). Found C (45.41), H (7.15), N (3.83).

Dibutyltin-methoxy-4-pyridinecarboxylate $\left[\left(\mathrm{C}_{6} \mathrm{H}_{4} \mathrm{NO}_{2}\right)\left(\mathrm{CH}_{3} \mathrm{O}\right) \mathrm{Sn}\left(\mathrm{C}_{4} \mathrm{H}_{9}\right)_{2}\right]$ (12). Using the same method reported for 10, III $\left(0.5 \mathrm{~g}(4.06 \mathrm{mmol})\right.$ of and $0.6 \mathrm{~mL}(0.436 \mathrm{~g}, 4.30 \mathrm{mmol})$ of $\mathrm{Et}_{3} \mathrm{~N}$ in a mixture of $30 \mathrm{~mL}$ of toluene and $10 \mathrm{~mL}$ of ethanol, was mixture with $1.39 \mathrm{~g}(4.57 \mathrm{mmol})$ of dibutyltin dichloride and $0.6 \mathrm{~mL}(0.436 \mathrm{~g}, 4.30 \mathrm{mmol})$ of $\mathrm{Et}_{3} \mathrm{~N}$ in solution of $30 \mathrm{~mL}$ of toluene and $10 \mathrm{~mL}$ of ethanol, the product was a yellow liquid, yield $>90 \%$, IR (solid, v): $1394(\mathrm{C}=\mathrm{O}$ sym), $1598(\mathrm{C}=\mathrm{O}$ asym), 1549 (C=C py), $1468\left(\mathrm{C}=\mathrm{N}\right.$ py), $491(\mathrm{Sn}-\mathrm{C}), 437(\mathrm{Sn}-\mathrm{O})$; NMR $\left(\mathrm{CDCl}_{3}\right):{ }^{119} \mathrm{Sn}$ : not observed; ${ }^{1} \mathrm{H}$ : H2 (8.582), H3 (7.676), H5 (7.676), H6 (8.582), H8 (1.656), H9 (1.34), H10 (1.34), H11 (0.957), O-Me (3.05); ${ }^{13} \mathrm{C}: \mathrm{C} 2$ (150.3), C3 (123.7), C4 (141.7), C5 (123.1), C6 (150.3), C7 (170.9), C8 (28.2), C9 (27.7), C10 (27.3), C11 (13.9), O-Me (46.2); Elem. anal. [ $\left.\mathrm{C}_{15} \mathrm{H}_{25} \mathrm{NO}_{3} \mathrm{Sn}\right]$ Calc. C (46.67), H (6.53), N (3.63). Found C (45.41), H (7.33), N (3.99).

\subsection{Thin Layer Chromatographic (TLC) profile modified with DPPH method}

The methodology reported by Conforti et al. [54] was applied with modifications, due to the fact that characteristically the organometallic fragment of stannoxanes can bind to the TLC layer and possibly leave free the organic fragment; in this case the chromatographic layer was not developed in any solvent, so, the stannoxanes were applied in the TLC layer and left to dry under room conditions. A $200 \mu \mathrm{g} / \mathrm{mL} \mathrm{CHCl}_{3}$ solution of each stannoxane 1-12 as well as the ligands I-III and a $0.2 \%$ DPPH methanolic solution were prepared. A standard of vitamin $\mathrm{C}$ at $200 \mu \mathrm{g} / \mathrm{mL}$ concentration was also prepared. After that they were applied to TLC layers as spots of approximately $10 \mu \mathrm{L}$ of each compound as well as the vitamin $\mathrm{C}$ standard and allowed to dry under room conditions for $30 \mathrm{~min}$. Then the layers were submerged in $0.2 \% \mathrm{DPPH}$ solution. Once the reaction of the free stable radical was finished (about 5-8 min) a discoloration was shown in the spot applied for any compound showing antioxidant activity. 


\subsection{Antiradical activity measurement with $D P P H$}

The antiradical activity of the stannoxanes derived from pyridinecarboxylic acids was carried out using the method proposed by Blois [55]; dilutions in DMSO solvent for the 12 stannoxanes and ligands I-III at $20 \mu \mathrm{g} / \mathrm{mL}$, and a $0.01 \mathrm{mM}$ methanolic solution of DPPH stable radical were prepared.

Dilutions of the stannoxanes and ligands were applied in a 96-well microplate and a blank without sample was also prepared. After the application of all the compounds the $0.01 \mathrm{mM}$ DPPH solution was added and absorbance at time zero $(\mathrm{T}=0)$ was immediately measured using a UV wavelength of $570 \mathrm{~nm}$. Measurements were performed every $5 \mathrm{~min}$ until $30 \mathrm{~min}$ was completed and every 15 min until $90 \mathrm{~min}$ were completed. Vitamin $\mathrm{C}$ was used as standard molecule at a $20 \mu \mathrm{g} / \mathrm{mL}$ concentration.

Antiradical activity evaluation for stannoxanes 1-12 and ligands I-III was measured in terms of absorbance decrease at $570 \mathrm{~nm}$ of DPPH methanolic solution produced by the effect of each stannoxane or ligand as a result of their ability to donate a hydrogen giving place to the reduced form of DPPH radical (pale yellow solution). The amount of DPPH reduced form was determined in every established period of time using the following equation: [(Ao-Ae)/Ao]*100, where Ao corresponds to the absorbance of sample without stannoxane and Ae corresponds to the absorbance of sample with stannoxane.

In this article, we decided to do an analysis of antiradical activity at $60 \mathrm{~min}(\mathrm{~T}=60 \mathrm{~min})$ at $20 \mu \mathrm{g} / \mathrm{mL}$ concentration in order to present the best activity for each compound and ligand and be able to evaluate the structure-activity relationships $[42,50]$.

\subsection{Ferric-reducing antioxidant power assay (FRAP)}

The ability of the stannoxanes $\mathbf{1 - 1 2}$ as well as the ligands I-III to reduce iron(III) was carried out by the method reported by Hinneburg et al. [52], scaling it to a micro method as follows: a $2 \mu \mathrm{g} / \mathrm{mL}$ solution of each stannoxane and ligand in DMSO was prepared. In an assay tube $400 \mu \mathrm{L}$ of stannoxane solution, $1000 \mu \mathrm{L}$ of PBS buffer, and $1000 \mu \mathrm{L}$ of $\mathrm{K}_{3} \mathrm{Fe}(\mathrm{CN})_{6}$, were added and this mixture was incubated for $30 \mathrm{~min}$ at $50{ }^{\circ} \mathrm{C}$, after this, $10 \%$ trichloroacetic acid solution $(1000 \mu \mathrm{L})$ was added to the sample and this mixture was stirred for one minute and centrifuged at 1,500 rpm for $10 \mathrm{~min}$; after the centrifugation a $1000 \mu \mathrm{L}$ aliquot of the supernatant was taken and transferred to a clean assay tube where $0.1 \% \mathrm{FeCl}_{3}$ solution $(200 \mu \mathrm{L})$ was added. The absorbance of this mixture was recorded at $700 \mathrm{~nm}$ in an UV-spectrophotometer, the values are presented as means $\pm \mathrm{SD}, \mathrm{n}=3$.

\section{Conclusions}

Two methods were used to determine the antioxidant power of stannoxanes; the proton and the electron donating ability were determined, and the results show that the bound and free pyridine and carboxylic nuclei were determinant for this, and the butyl- and phenyl groups play an important role in tin(IV) coordination, because of their electron-donating and electron-withdrawing capabilities. The results show that six of the twelve stannoxanes evaluated are good radical scavengers, compounds $\mathbf{5}>\mathbf{6}=\mathbf{1 1}$ in the DPPH quantitative assay and compounds $\mathbf{8}>\mathbf{7}=\mathbf{3}$ in the FRAP method. The most promising compound, in the context of this work, is compound 5. For DPPH, diphenyltin and dibutyltin (hexa- and pentacoordinated respectively) were the best, being the most active diphenyltin- 
bis-(3-pyridinecarboxylate) (compound 5) the most active. In the FRAP method tributyltin-3pyridinecarboxylate (compound $\mathbf{8}$, tetracoordinated) was the most active derivative.

\section{Acknowledgments}

C.-B. A. is grateful for a scholarship and grant No. 201655 from CONACYT-Mexico. Financial support by CONACYT No. 52156 and FRABA-U. de C. No. 460/07 is also acknowledged.

\section{References}

1. Berners, S.J. Metals in medicine. Keynote Lectures. KL01:The mitochondrial cell death pathway as a target for gold and other metal-based antitumor compounds. J. Biol. Inorg. Chem. 2007, 12, S7-S52.

2. Farrell, N. Metals in medicine. Keynote Lectures. KL02: Transplatinum compounds as anticancer agents. A real posibility? J. Biol. Inorg. Chem. 2007, 12, S7-S52.

3. Hambley, T.W. Metals in medicine. Keynote Lectures. KL03:The distribution and biotransformation of metal based anticancer agents in cancer cells and tumor models. J. Biol. Inorg. Chem. 2007, 12, S7-S52.

4. Orving, C. Metals in medicine. Multifunctional carbohydrate-appended metal complexes as potential agents in alzheimer's disease therapy. J. Biol. Inorg. Chem. 2007, 12, S7-S52.

5. Crichton, R. Metals in medicine. Keynote lectures. SL006: Iron generated reactive oxygen species and neurodegenerative diseases. J. Biol. Inorg. Chem. 2007, 12, S7-S52.

6. Clarke, M.J. Metals in medicine. Keynote lectures. SL005: Overview of non-platinum therapeutic and diagnostic agents. J. Biol. Inorg. Chem. 2007, 12, S7-S52.

7. Mendes, I.C.; Moreira, J.P.; Ardisson, J.D.; Santos, R.G.D.; Silva, P.R.O.D.; García, I.; Castiñeiras, A.; Beraldo, H. Organotin(IV) complexes of 2-pyridineformamide-derived thiosemicarbazones: Antimicrobial and cytotoxic effects. Eur. J. Med. Chem. 2007, 1-8.

8. Tripathi, U.N.; Ahmad, M.S.; Venubabu, G.; Ramakrishna, P. Synthesis, spectral and antimicrobial studies of triorganotin(IV) 3(2'-hydroxyphenyl)-5-(4-substituted phenyl) pyrazolinates. J. Coord. Chem. 2007, 1-12.

9. Bernhardt, P. Metals in medicine. Keynote lectures. SL003: Chelators for the treatment of iron overload diseases. . J. Biol. Inorg. Chem. 2007, 12, S7-S52.

10. Jiménez-Pérez, V.M.; Camacho-Camacho, C.; Ramos-Organillo, A.; Ramirez-Trejo, R.; PeñaHueso, A.; Contreras, R.; Flores-Parra, A. Hypervalent and binuclear silicon and germanium derivatives from bis-(3,5-di-tert-butyl-2-phenol)-oxamide. J. Organomet. Chem. 2007, 692, 5549-5554.

11. Peña-Hueso, A.; Esparza-Ruiz, A.; Ramos-García, I.; Flores-Parra, A.; Contreras, R. Triphenyl lead, tin and germanium coordination compounds derived from 9H-3-thia-1, 4a, 9-triaza-fluorene2,4-dithione. J. Organomet. Chem. 2008, 693, $492-504$.

12. Gleeson, B.; Claffey, J.; Ertler, D.; Hogan, M.; Müller-Bunz, H.; Paradisi, F.; Wallis, D.; Tacke, M. Novel organotin antibacterial and anticancer drugs. Polyhedron 2008, 27, 3619-3624. 
13. Mendes, I.C.; Moreira, J.P.; Ardisson, J.D.; dos Santos, R.G.; da Silva, P.R.O.; Garcia, I.; Castineiras, A.; Beraldo, H. Organotin(IV) complexes of 2-pyridineformamide-derived thiosemicarbazones: Antimicrobial and cytotoxic effects. Eur. J. Med. Chem. 2008, 43, 1454-1461.

14. Katsoulakou, E.; Tiliakos, M.; Papaefstathiou, G.; Terzis, A.; Raptopoulou, C.; Geromichalos, G.; Papazisis, K.; Papi, R.; Pantazaki, A.; Kyriakidis, D.; Cordopatis, P.; Manessi-Zoupa, E. Diorganotin(IV) complexes of dipeptides containing the alpha-aminoisobutyryl residue (Aib): Preparation, structural characterization, antibacterial and antiproliferative activities of [(n$\mathrm{Bu}$ (2)Sn(H-L-1)] (LH = H-Aib-L-Leu-OH, H-Aib-L-Ala-OH). J. Inorg. Biochem. 2008, 102, 1397-1405.

15. Nath, M.; Sulaxna; Song, X.; Eng, G.; Kumar, A. Synthesis and spectral studies of organotin(IV) 4-amino-3-alkyl-1,2,4-triazonle-5-thionates: In vitro antimicrobial activity. Spectrochim. Acta Part A 2008, 70, 766-774.

16. Joshi, R.; Kumar, P.; Kumar, V.; Hashmi, A.A., Organotin(IV) oxo-homoscorpionate: preparation, spectroscopic characterization and antimicrobial properties. J. Coord. Chem. 2008, 61, 1283-1293.

17. Balas, V.I.; Hadjikakou, S.K.; Hadjiliadis, N.; Kourkoumelis, N.; Light, M.E.; Hursthouse, M.; Metsios, A.K.; Karkabounas, S. Crystal structure and antitumor activity of the novel zwitterionic complex of tri-n-Butyltin(IV) with 2-thiobarbituric acid. Bioinorg. Chem. Appl. 2008, 2008, 1-5.

18. Kovala-Demertzi, D.; Dokorou, V.; Primikiri, A.; Vargas, R.; Silvestru, C.; Russo, U.; Demertzis, M.A. Organotin meclofenamic complexes: Synthesis, crystal structures and antiproliferative activity of the first complexes of meclofenamic acid - Novel anti-tuberculosis agents. J. Inorg. Biochem. 2009, 103, 738-744.

19. Hadjikakou, S.K.; Hadjiliadis, N. Antiproliferative and anti-tumor activity of organotin compounds. Coord. Chem. Rev. 2009, 253, 235-249.

20. Nath, M.; Jairath, R.; Eng, G.; Song, X.Q.; Kumar, A. Synthesis, spectral characterization and biological studies of some organotin(IV) complexes of L-proline, trans-hydroxy-L-proline and Lglutamine. Spectrochim. Acta Part a-Mol. Biomol. Spec. 2005, 62, 1179-1187.

21. Nath, M.; Pokharia, S.; Eng, G.; Song, X.Q.; Kumar, A. New triorganotin (IV) derivatives of dipeptides as models for metal-protein interactions: Synthesis, structural characterization and biological studies. Spectrochim. Acta Part a-Mol. Biomol. Spec. 2006, 63, 66-75.

22. Rauf, M.K.; Saeed, M.A.; Imtiaz ud, D.; Bolte, M.; Badshah, A.; Mirza, B. Synthesis, characterization and biological activities of some new organotin(IV) derivatives: Crystal structure of $[(\mathrm{Sn} \mathrm{Ph}-3)(\mathrm{OOCC} 6 \mathrm{H} 4 \mathrm{OH})]$ and $[(\mathrm{SnMe} 3)(2)(\mathrm{OOC})(2) \mathrm{C} 6 \mathrm{Cl} 4$ (DMSO)(2)]. J. Organomet. Chem. 2008, 693, 3043-3048.

23. Gonzalez, A.; Gomez, E.; Cortes-Lozada, A.; Hernandez, S.; Ramirez-Apan, T.; Nieto-Camacho, A. Heptacoordinate Tin(IV) Compounds Derived from Pyridine Schiff Bases: Synthesis, Characterization, in Vitro Cytotoxicity, Anti-inflammatory and Antioxidant Activity. Chem. Pharm. Bull.2009, 57, 5-15.

24. Carrera, N.; Gutiérrez, E.; Benavente, R.; Villavieja, M.M.; Albéniz, A.C.; Espinet, P. Stannylated Polynorbornenes as New Reagents for a Clean Stille Reaction. Chem. Eur. J. 2008, 14, 10141-10148. 
25. Dokorou, V.N.; Kovala-Demertzi, D.; Louloudi, M.; Silvestru, A.; Demertzis, M.A. Synthesis, characterization and catalytic properties of diorganotin derivatives. Crystal and molecular structure of the first complex of 2-(2-methyl-3-nitroanilino)benzoic acid of 1,2:3,4-di-12-2-(2methyl-3-nitroanilino)benzoato-O,O-1,3-bis-2-(2-methyl-3-nitroanilino)-benzoato-O-1,2,4:2,3,4di-13-oxo-tetrakis[di-methyltin(IV)]. J. Organomet. Chem. 2008, 693, 3587-3592.

26. Bukhari, S.B.; Memon, S.; Mahroof-Tahir, M.; Bhanger, M.I. Synthesis, characterization and antioxidant activity copper-quercetin complex. Spectrochim. Acta Part a-Mol. Biomol. Spec. 2009, 71, 1901-1906.

27. Chen, W.; Sun, S.; Cao, W.; Liang, Y.; Song, J. Antioxidant property of quercetin-Cr(III) complex: The role of Cr(III) ion. J. Mol. Struct. 2009, 918, 194-197.

28. Bukhari, S.B.; Memon, S.; Tahir, M.M.; Bhanger, M.I. Synthesis, characterization and investigation of antioxidant activity of cobalt-quercetin complex. J. Mol. Struct. 2008, 892, 39-46.

29. Gabrielska, J.; Soczynska-Kordala, M.; Hladyszowski, J.; Zylka, R.; Miskiewicz, J.; Przestalski, S., Antioxidative effect of quercetin and its equimolar mixture with phenyltin compounds on liposome membranes. J. Agric. Food Chem. 2006, 54, 7735-7746.

30. Gabrielska, J.; Monika, S.-K.; Prestalski, S. Antioxidative effecto of kempferol and its equimolar mixture with phenyltin compounds on UV-irradiated liposome membranes. J. Agric. Food Chem. 2005, 53, 76-83.

31. Bardak, F.; Atac, A.; Kurt, M. Infrared and Raman study of some isonicotinic acid metal(II) halide adn tetracyanonickelate complexes. Spectrochim. Acta A 2009, 71, 1896-1900.

32. Carlson, L.A. Nicotinic acid: the broad-spectrum lipid drug. A 50th anniversary review. J. Intern. Med. 2005, 258, 94-114.

33. Kalinowska, M.; Borawska, M.; Swislocka, R.; Piekut, J.; Lewandowski, W. Spectroscopic (IR, Raman, UV, 1H and 13C NMR) and microbiological studies of Fe(II), Ni(II), Cu (II), Zn(II) and Ag(I) picolinates J. Mol. Struct. 2007, 834, 419-425.

34. Morton, I.K.M.; Hall, J.M.P. Nicotinic Acid. In Concise Dictionary of Pharmacological Agents Properties and Synonyms, 1st ed.; Springer-Verlag: London, UK, 1999.

35. Basu, T.K.; Mann, S. Vitamin B6 Normalizes the Altered Sulfur Amino Acid Status of Rats Fed Diets containing Pharmacological Levels of Niacin without Reducing Niacin's Hypolipidemic Effects. J. Nutr. 1997, 127, 117-121.

36. Szorcsik, A.; Nagy, L.; Scopelliti, M.; Deak, A.; Pellerito, L.; Galbács, G.; Hered, M. Preparation and structural characterization of [Ph3Sn(IV)]+ complexes with pyridine-carboxylic acids of hydroxypyridine, -pyrimidine and quinoline. J. Organomet. Chem. 2006, 691, 1622-1630.

37. Theo, S.-G.; Ang, S.-H.; Lim, H.-C.; Fun, H.-K.; Ibrahim, A.R., Syhtesis and Crystal Structure of Polymeric Triphenyltin(IV) 4-pyridinecarboxylate. J. Coord. Chem. 1998, 46, 87-96.

38. Win, Y.F.; Guan, T.S.; Yamin, B.M. Synthesis and characterization of tributyltin(IV) complexes derived from pyridine monocarboxylic acids. The Malaysian J. Anal. Sci. 2006, 10, 285-294.

39. Corona-Bustamante, A. Sintesis, caracterización y evaluación farmacológica de estanoxanos derivados de los ácidos [2-], [3-] y 4-piridín carboxilicos. Doctoral Thesis, Universidad de Colima, Coquimatlán, Colima, 2009. 
40. Gielen, M.; Dalil, H.; Ghys, L.; Boduszek, B.; Tienkink, E. R. T.; Martins, J. C.; Biesemans, M.; Willem, R., Synthesis and structure of di-n-butyltin pyridine-2-phosphonate-6-carboxylate. Organometallics 1998, 17, 4259-4262.

41. Bafna, A.; Mishra, S. Actividad antioxidante in vitro del extracto de metanol de los rizomas de Curculigo orchioides Gaertn. Ars. Pharm. 2005, 46, 125-138.

42. Molyneux, P. The use of the stable free radical diphenylpicrylhydrazyl (DPPH) for estimating antioxidant activity. Songklanakarin J. Sci. Technol. 2004, 26, 211-219.

43. Pérez, R.; Vargas, R.; Martínez, F.; García, E.; Hernández, B., Antioxidant activity of alkaloids from Bocconia arborea. A study on six testing methods. Ars. Pharm. 2003, 44, 5-21.

44. Bukhari, S.B.; Memon, S.; Tahir, M.M.; Bhanger, M.I. Synthesis, characterization and investigation of antioxidant activity of cobalt-quercetin complex. J. Mol. Struct. 2008, 892, 39-46.

45. Chen, W.; Sun, S.; Cao, W.; Liang, Y.; Song, J. Antioxidant property of quercetin-Cr(III) complex: The role of Cr(III) ion. J. Mol. Struct. 2009, 918, 194-197.

46. Gabrielska, J.; Sczynska, M.; Prezestalski, S. Antioxidative effect of kaempferol and its equimolar mixture with phenyltin compounds on UV-irradiated liposome membranes. J. Agric. Food Chem. 2005, 53, 76-83.

47. Carlson, L.A. Nicotinic acid: the broad-spectrum lipid drug. A 50th anniversary review. J. Int. Med. 2005, 258, 94-114.

48. Bardak, F.; Atac, A.; Kurt, M. Infrared and Raman study of some isonicotinic acid metal (II) halide and tetracyanonickelate complexes. Spectrochim. Acta Part A 2009, 71, 1896-1900.

49. Murakami, K.; Tanemura, Y.; Yoshino, M. Dipicolinic acid prevents the copper-dependent oxidation of low density lipoprotein. J. Nutr. Biochem. 2003, 14, 99-103.

50. Topçu, G.; Ertaş, A.; Kolak, U.; Öztürk, M.; Ulubelen, A. Antioxidant activity tests on novel triterpenoids from Salvia macrochlamys. Arkivoc 2007, vii, 195-208.

51. Appel, K.E. Organotin Compounds: Toxicokinetic Aspects. Drug Metab. Rev. 2004, 36, 763-786.

52. Hinneburg, I.; Dorman, H.J.D.; Hiltunen, R. Antioxidant activities of extracts from selected culinary herbs and spices. Food Chem. 2006, 97, 122-129.

53. Harris, R.K.; Becker, E.D.; Cabral de Menezes, S.M.; Goodfellow, R.; Granger, P. NMR nomenclature: nuclear spin properties and conventions for chemical shifts. IUPAC Recommendations 2001. Magn. Reson. Chem. 2002, 40, 489.

54. Conforti, F.; Marrelli, M.; Statti, G.; Menichini, F. Antioxidant and cytotoxic activities of methanolic extract and fractions from Senecio gibbosus subsp. gibbosus (GUSS) DC. Nat. Prod. Res. 2006, 20, 805-812.

55. Blois, M.S. Antioxidant determinations by the use of a stable free radical. Nature 1958, 26, 1199-1200.

Sample Availability: Samples of the compounds are available from the authors.

(C) 2010 by the authors; licensee MDPI, Basel, Switzerland. This article is an Open Access article distributed under the terms and conditions of the Creative Commons Attribution license (http://creativecommons.org/licenses/by/3.0/). 